\title{
СИСТЕМА ПІДТРИМКИ ПРИЙНЯТТЯ РІШЕНЬ ПРИ ПРОВЕДЕННІ ВІТРЕКТОМІЇ У ХВОРИХ НА ДІАБЕТИЧНУ ПРОЛІФЕРАТИВНУ РЕТИНОПАТІЮ
}

А. М. Рубан

\author{
Національна медична академія післядипломної освіти імені П. А. Шупика
}

\begin{abstract}
Проведено ретроспективне дослідження 145 операцій (вітректомій) в неселективній когорті 145 пацієнтів (145 очей) з проліферативною діабетичною ретинопатією (ПДР) для визначення можливих прогностичних факторів незадовільного результату операцій. Загальну групу склали пацієнти з вітреоретинапьним крововиливом, тракційним або тракційно-регматогенним відшаруванням сітківки. На підставі дослідження та аналізу 145 клінічних ознак і 60 видів ускладнень нами було відібрано 33 фактори, що характеризують загальний стан і офтальмологічний статус пацієнта, які були об'єднані в карту ризику. Прогноз оперативного втручання у конкретних хворих визначали сумою балів ризику. Вивчали сумарний ризик на трьох вибірках - «навчальній» (145 пацієнтів), «контрольній» (50 пацієнтів) та екзаменаційній (3О спостережень). За результатами 225 спостережень визначена залежність несприятливого результату операції від суми балів ризику та виділені 4 ступені ризику оперативного втручання - низький ризик (перший ступінь ризику), відповідна ймовірність несприятливого результату менш ніж 0,05 , середній ризик - 3 ймовірністю несприятливого результату 0,05-0,4; виражений ризик - ймовірність несприятливого результату 0,41-0,9 і крайній ризик з ймовірністю поганого результату більше 0,9.
\end{abstract}

Ключові слова: прогнозування, система підтримки прийняття рішень, діабетична проліферативна ретинопатія, вітректомія.

\section{СИСТЕМА ПОДДЕРЖКИ ПРИНЯТИЯ РЕШЕНИЙ ПРИ ПРОВЕДЕНИИ ВИТРЭКТОМИИ У БОЛЬНЫХ ПРОЛИФЕРАТИВНОЙ ДИАБЕТИЧЕСКОЙ РЕТИНОПАТИЕЙ}

\begin{abstract}
А. Н. Рубан
Национальная медицинская академия последипломного образования имени П. Л. Шупика

Проведено ретроспективное исследование 145 операций (витрэктомий) в неселективной когорте 145 пациентов (145 глаз) с пролиферативной диабетической ретинопатией (ПДР) для определения возможных прогностических факторов неблагоприятного результата операции. В группу вошли пациенты с витреапьным кровоизлиянием, тракционной, (тракционно-регматогенной) отслойкой сетчатки. В результате исследования и анализа 145 клинических признаков и 60 видов осложнений нами были отобраны 33 фактора, характеризующих общее состояние пациента, офртальмологический статус, которые были объединены в карту риска. Прогноз оперативного вмешательства определялся суммой баллов риска. Изучался суммарный риск на трех выборках - «учебной» (145 пациентов), «контрольной» (50 пациентов) и «экзаменационной» (30 наблюдений). По результатам 225 наблюдений определена зависимость неблагоприятного результата операции от суммы балов риска и выделены 4 степени риска: низкий риск (первая ступень риска), когда вероятность неблагоприятного результата менее 0,05 ; средний риск - когда вероятность неблагоприятного результата составляет 0,05-0,4; высокий риск - вероятность неблагоприятного результата составляет 0,41-0,9 и крайний риск, когда вероятность неблагоприятного результата составляет более 0,9.
\end{abstract}

Ключевые слова: прогнозирование, система поддержки принятия решений, диабетическая пролиферативная ретинопатия, витрэктомия, семейная медицина.

\section{DECISION SUPPORT SYSTEMS TO THE CONSTRUCTION OF THE VITRECTOMY RISK MANAGEMENT SYSTEM IN PATIENTS WITH DIABETIC PROLIFERATIVE RETINOPATHY}

A. M. Ruban

\author{
National Medical Academy of Postgraduate Education by P. L. Shupyk
}

The article presents the some approaches to create a system support of making decision during miniinvasive diabetic vitrectomy in patients with diabetic proliferative retinopathy, promotes objective assessment of individual risk-management

О А. М. Рубан 


\section{МЕДИЧНА ІНФОРМАТИКА TA IHЖEHEPIЯ}

for patient and allows optimize ophthalmological care for them. This was a retrospective study of 145 patients (145 eyes) who underwent combined sutureless vitrectomy for the complications of proliferative diabetic retinopathy. The study and analysis of the clinical characteristics $(\mathrm{N}-145)$ and 60 kinds of complications have selected 33 factors, characterizing the general condition of the patient, ophthalmic status which have been integrated into the risk map. Prediction of surgical intervention was determined by the amount of points. Total risk was studied in three samples of "training" (145 patients), «control» (50 patients) and the "examination" (30 cases). Based on 225 observations determined the dependence of an adverse operation of points of risk and identified 4 risk levels: low risk (first stage), the likelihood of an adverse outcome is less than 0.05 ; average risk is the likelihood of an adverse outcome is $0.05-0.4$; high risk-the probability of an adverse up $0.41-0.9$ and extreme risks, the likelihood of an adverse outcome is greater than 0.9 .

Key words: predictive factors, system support of making decision, diabetic proliferative retinopathy, vitrectomy.

Вступ. Найефективнішим методом лікування ускладнених форм ироліферативної діабетичної ретинопатії (ПДР) сьогодні $є$ комплексне вітреоретинальне втручання, яке полягає у видаленні склоподібного тіла, висіченні фіброваскулярних мембран, розправленні та ендолазерокоагуляції ішемічної сітківки [1, 2]. Проте результат хірургічного лікування пацієнтів з ПДР залишається недостатньо прогнозованим і визначається багатьма, не до кінця вивченими факторами $[3,4]$. Існуючі на сьогодні офтальмологічні рекомендації ведення (в тому числі і хірургічного) хворих на цукровий діабет (I ІД) характеризують лише загальні лікувально-діагностичні принципи або розглядають тільки окремі варіанти перебігу захворювання, не враховуючи всі різновиди проявів патологічного процесу діабетичного ураження сітківки.

Мета дослідження. Обгрунтування і побудова системи управління тактикою та стратегією лікування хворих з проліферативною діабетичною ретинопатією (ПДР) з урахуванням прогностичної цінності клінічних ознак як факторів ризику незадовільного результату хірургічного лікування пацієнтів.

Матеріали і методи. Проведено ретроспективне дослідження 145 операцій (вітректомій) у 145 пацієнтів (145 очей) з ПДР для визначення можливих прогностичних факторів незадовільного результату операцій. Загальну групу склали пацієнти з вітрсорстинальним крововиливом, тракційним або тракційно-регматогенним відшаруванням сітківки. У групу не ввійшли пацієнти 3 первинним регматогенним відшаруванням сітківки, увеїтом або травмою. Мінімальний термін спостереження склав 6 місяців. Чоловіків було 62 (42,7 \%), жінок - 83 (57,3\%). До групи увійшло 89 (62 \%) пацієнтів 31 типом цукрового діабету, 56 (38 \%) пацієнтів з 2 типом цукрового діабету, тривалість діабету $>15$ років відзначена у $137(95 \%)$ паціснтів, $\mathrm{i}<15$ років у $8(5 \%)$ хворих. Вік пацієнтів становив від 17 до 75 років, 49 пацієнтів (34 \%) були молодше 50 років, та 96 пацієнтів $(66 \%)$ - старше 50 років.
Доопераційне обстеження включало: визначення гостроти зору, біомікросюпію, офтальмоскопію, статичну і динамічну периметрії, тонометрію, ультразвукове сканування (при неможливості огляду очного дна), флуоресцентну ангіографію (для визначення макулярної ішемії сітківки), оптичну когерентну томографію (для діагностики макулярного набряку, розриву сітківки, вітреомакулярноїтракції). Гостроту зору визначали за таблицею Сівцева-Головіна.

Операції виконували за методикою 3-портової вітректомії (моно- або бімануальною технікою) 3 використанням різних калібрів інструментів 23/25G. Видалялось центральне склоподібне тіло, проводили усунення передньо-задніх тракцій та максимально повне видалення фіброваскулярних мембран з задньою гіалоідною мембраною технікою деламінації, сегментації або висічення «єдиним блоком». При необхідності проводили панретинальну ендолазерокоагуляцію сітківки. Дія візуалізації очного дна використовували ширококутову систему візуалізації очного дна BIOM (Oculus, Germany) або OFFISS (Topcon, Japan). При необхідності проведення хірургічних маніпуляцій на макуіярній ділянці сітківки ми використовували контактні лінзи (Dorc, Netherlands). У більшості випадків проводили одночасну факоемульсифікацію кришталика 3 імплантацією м'якої ЮЛ. Силіконову або газову тампонаду проводили за показаннями [5].

Пошук "факторів ризику" визначався ймовірністю виникнення незадовільного кінцевого функціонального результату операції при наявності або відсутності ознаки. Обчислення прогностичної значимості ознак проводилося за методикою М. М. Амосова зі співавторами (1972) та полягало в порівнянні частоти несприятливого результату у хворих при наявності досліджуваної ознаки з частотою несприятливого результату у всіх хворих, обстежених на даним показником. Було проаналізовано 145 ознак, що характеризують дані анамнезу, соматичного стану, клінічного обстеження, лабораторних, спеціальних та 
інструментальних методів обстеження, особливості інтраопераційної техніки а також різні види ускладнень (в ранньому та пізньому післяопераційному періоді) $[6,7]$.

Результати та їх обговорення. Прогнозування операційних ризиків завжди пов' язане з реально існуючим процесом. Зрозуміло, що хід патологічного процесу в наступні моменти часу визначається не тільки значенням показників у певний момент часу, але й реалізацією в попередні моменти часу - так званою передісторією [8]. Найбільші труднощі при побудові системи управління ризиками полягають у відпрацюванні правил прийняття рішень для побуцови плану обстежень пацієнтів та вибору оптимального (в значенні мінімізації ускладнень) методу лікування.

Структура прогностичної системи при вітреоретинальному втручанні (як і взагалі при створенні систем предикції) залежить від вирішення двох принципових питань - створення апріорної класифікації станів і симптомів (медичне забезпечення) та обгрунтування послідовності етапів прогнозування їх наслідків.

Для вирішення завдання по прогнозуванню на практиці застосовували відносно прості методики, пов'язані з бальними критеріями, при яких одне з провідних місць займає визначення прогностичної значимості клінічних ознак. Тому найважливішим завданням в процесі створення системи управління ризиками було виділення та систематизація ознак, що мають найбільше значення для перебігу та результату патологічного процесу, які були попередньо згруповані лікарем. На підставі дослідження та аналізу 145 клінічних ознак і 60 видів ускладнень нами було відібрано 33 фактори, що характеризують загальний стан і офтальмологічний статус пацієнта. Перед складанням карти ризику перевіряли взаємозв'язок (кореляцію) параметрів. При наявності такої, вибирали один з них або зменшували цінність обох параметрів.

У результаті були визначені найбільш значимі показники, які і були об'єднані в карту ризику. У таблиці 1 наведені найважливіші з них.

Прогноз оперативного втручання у конкретних хворих визначали сумою балів ризику. Вивчали сумарний ризик на трьох вибірках: «навчальній» (145 пацієнтів), «контрольній» (50 пацієнтів) «екзаменаційній» (30 спостережень).

Перший етап цієї частини дослідження проводили на навчальній вибірці, тобто на тій, на якій власне i були отримані фактори ризику. Контрольна вибірка призначена для перевірки можливих статистичних закономірностей. Ще раз підкреслимо, що всі спостереження мали верифіковані висновки.

Таблиця 1. Карта ризику вітректомії при проліферативній діабетичній ретинопатії

\begin{tabular}{|c|c|}
\hline Фактор ризику & $\begin{array}{l}\text { Значи- } \\
\text { мість } \\
\text { у балах }\end{array}$ \\
\hline \multicolumn{2}{|l|}{ Загальні фактори } \\
\hline Субкомпенсований загальний стан & 3,1 \\
\hline Тривалість діабету більш ніж 15 років & 2,1 \\
\hline Гіпоглікемія & 2,4 \\
\hline Енцефалопатія & 2,0 \\
\hline Ниркова недостатність & 5,4 \\
\hline Переміжна кульгавість & 2,3 \\
\hline Втрата чутливості кінцівок & 2,2 \\
\hline Набряки кінцівок & 4,6 \\
\hline Глюкозурія & 4,9 \\
\hline Ацетонурія & 2,0 \\
\hline Альбумінурія & 4,1 \\
\hline Гемоглобін менше 100 г/л & 4,7 \\
\hline \multicolumn{2}{|l|}{ Офтальмологічний статус } \\
\hline $\begin{array}{l}\text { Максимально корегована гострота зору } \\
<0,05\end{array}$ & 2,1 \\
\hline Загальне поле зору (градуси) <300 & 4,8 \\
\hline Повільна реакція зіниці на світло & 3,0 \\
\hline $\begin{array}{l}\text { Тракційне відшарування сітківки } \\
\text { за типом «площинна» }\end{array}$ & 2,0 \\
\hline $\begin{array}{l}\text { Зони неперфузії сітківки: } \\
3 \text { квадранти; } \\
4 \text { квадранти }\end{array}$ & $\begin{array}{l}2,1 \\
3,0\end{array}$ \\
\hline Попередня лазерна коагуляція не виконана & 3,0 \\
\hline Центральна скотома & 3,9 \\
\hline Аферентний зіничний дефект & 2,9 \\
\hline Медикаментозний мідріаз менше ніж 4 мм & 3,3 \\
\hline Рубеоз райдужки & 2,5 \\
\hline Тракційне відшарування макули & 2,6 \\
\hline Атрофія зорового нерва & 3,6 \\
\hline
\end{tabular}

Результати прогнозування результатів вітректомії в двох вибірках наведені в таблиці 2.

Як зрозуміло 3 наведеної таблиці, відзначається хороший збіг результатів дослідження залежності частоти несприятливих результатів від суми балів ризику. Наявні відмінності статистично недостовірні ( $<<1,64$ для $\mathrm{p}=0,05)$.

Отримані дані дали підставу для перевірки подібної статистичної залежності на експериментальному клінічному матеріалі. Розглядалися результати про- 
гнозування виходу хірургічного лікування проліферативної діабетичної ретинопатії у 30 хворих (табл. 3 ).
Верифікація виходу визначалася на підставі результатів оперативного втручання.

Таблиця 2. Прогнозування результатів оперативного втручання у хворих на проліферативну діабетичну ретинопатію за даними у навчальній та контрольній вибірках

\begin{tabular}{|c|c|c|c|c|c|c|c|}
\hline \multirow{3}{*}{$\begin{array}{l}\text { Сума } \\
\text { балів }\end{array}$} & \multicolumn{3}{|c|}{ «Навчальна» вибірка } & \multicolumn{3}{|c|}{ «Контрольна» вибірка } & \multirow{3}{*}{$\mathrm{z}^{*}$} \\
\hline & \multirow[t]{2}{*}{ всього спостережень } & \multicolumn{2}{|c|}{$\begin{array}{c}\text { несприятливий } \\
\text { результат }\end{array}$} & \multirow[t]{2}{*}{ всього спостережень } & \multicolumn{2}{|c|}{$\begin{array}{c}\text { несприятливий } \\
\text { результат }\end{array}$} & \\
\hline & & aбc. & $\%$ & & абс. & $\%$ & \\
\hline$<5$ & 30 & 2 & 6,7 & 10 & 0 & 0,0 & 0,81 \\
\hline $5-10$ & 30 & 3 & 10,0 & 10 & 1 & 10,0 & 0,14 \\
\hline $11-15$ & 36 & 8 & 22,2 & 13 & 3 & 23,1 & 0,25 \\
\hline $16-20$ & 35 & 24 & 68,6 & 11 & 8 & 72,7 & 0,27 \\
\hline $21-30$ & 10 & 9 & 90,0 & 4 & 4 & 80,0 & 0,25 \\
\hline$>30$ & 4 & 4 & 100,0 & 2 & 2 & 100,0 & 0 \\
\hline Всього & 145 & 50 & 34,5 & 50 & 18 & 36,0 & 0,25 \\
\hline
\end{tabular}

z" - критерій відмінності між «навчальною» та «контрольною» вибіркою.

Таблиця 3. Прогнозування результатів оперативного втручання у хворих на проліферативну діабетичну ретинопатію на поточних спостереженнях

\begin{tabular}{|c|c|c|c|c|}
\hline \multirow{2}{*}{ Сума балів } & \multirow{2}{*}{ Всього спостережень } & \multicolumn{2}{|c|}{ Несприятливий результат } & \multirow{2}{*}{$\mathrm{z}^{*}$} \\
\cline { 3 - 5 } & 5 & абс. & 0,0 & 0,89 \\
\hline$<5$ & 6 & 1 & 16,7 & 0,33 \\
\hline $5-10$ & 6 & 2 & 33,3 & 0,16 \\
\hline $11-15$ & 8 & 5 & 62,5 & 0,08 \\
\hline $16-20$ & 4 & 3 & 75,0 & 0,16 \\
\hline $21-30$ & 1 & 1 & 100,0 & 0,02 \\
\hline$>30$ & 30 & 12 & 40,0 & 0,56 \\
\hline
\end{tabular}

z * - критерій відмінностей між «екзаменаційною» $\mathrm{i}$ «контрольною» вибіркою

Дані таблиці 3 переконливо свідчать про збереження раніше виявленої закономірності, що підтверджується статистичними розрахунками. Порівняння трьох тенденцій за допомогою z-критерію не виявило відмінностей $(\mathrm{p}=0,05)$. Останне дало можливість об'єднати всі досліджені вибірки для отримання надійних результатів. У таблиці 4 підсумовані результати. Як видно $з$ таблиці 4, залежність має S-подібний характер і може бути апроксимована математичним виразом: $\mathrm{Y}=1-e^{-k(x-20)^{2}}$, де $k=4 \times 10^{-4}$.

Таблиця 4. Залежність несприятливого результату операції від суми балів ризику (225 спостережень)

\begin{tabular}{|c|c|c|c|c|}
\hline \multirow{2}{*}{ Сума балів } & \multirow{2}{*}{ Всього спостережень } & \multicolumn{3}{|c|}{ Несприятливий результат } \\
\cline { 3 - 5 } & & абс. & $\%$ & \pm m \\
\hline$<5$ & 45 & 2,0 & 4,4 & 3,1 \\
\hline $5-10$ & 46 & 5,0 & 10,9 & 5,6 \\
\hline $11-15$ & 55 & 13,0 & 68,5 & 5,7 \\
\hline $16-20$ & 54 & 37,0 & 88,9 & 7,3 \\
\hline $21-30$ & 18 & 16,0 & 100,0 & 0,0 \\
\hline$>30$ & 7 & 7,0 & 35,6 & 1,0 \\
\hline Всього & 225 & 80,0 & & \\
\hline
\end{tabular}

Визначена нами залежність представлена на рисунку 1. 


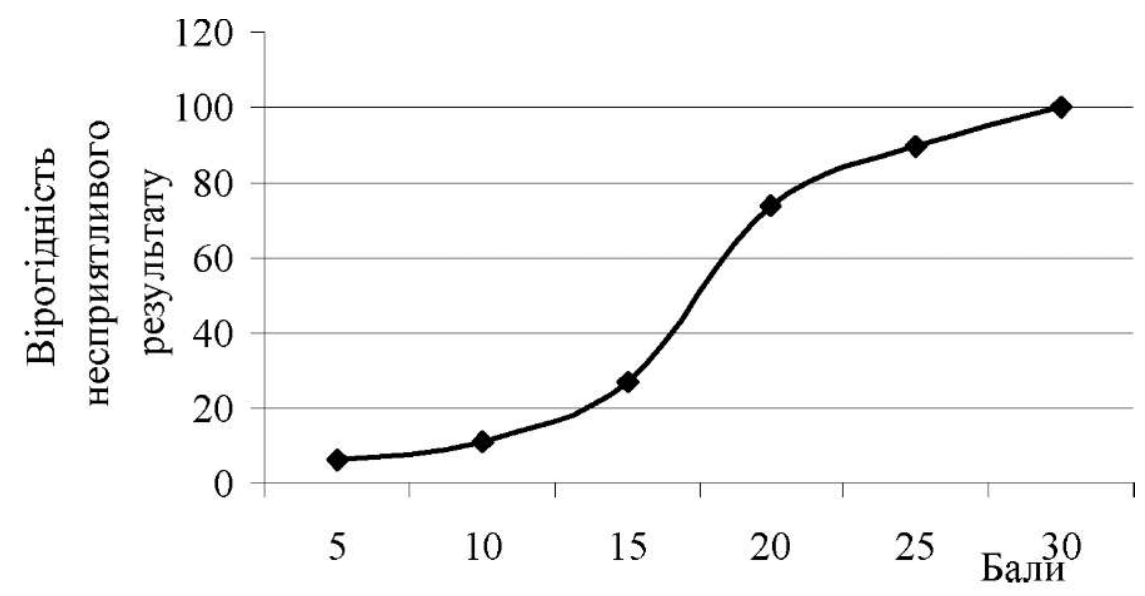

Puc.1. Вірогідність несприятливого результату вітректомії залежно від суми балів.

Оцінюючи характер отриманої кривої можна виділити 4 ступені ризику оперативного втручання - низький ризик (перший ступінь ризику), відповідна ймовірність несприятливого результату менше 0,05 i відображає нижню, майже горизонтальну частину кривої, середній ризик - 3 ймовірністю несприятливого результату 0,05-0,4; виражений ризик ймовірність несприятливого результату - 0,41-0,9 і крайній ризик з ймовірністю поганого результату більше 0,9 .

Оцінка сумарного ризику є необхідним компонентом при розробці рекомендацій в профілактичній офтальмології, особливо в індивідуальній профілактиці, або, як визначають експерти ВООЗ, у стратегії високого ризику, коли об'єктом профілактичного втручання є конкретний пацієнт або невелика група (когорта) пацієнтів, які мають схожі характеристики за основними факторами, які впливають на прогноз операції.

Безумовно, при плануванні хірургічного втручання (вітректомії) аналіз інформації, що визначає стан пацієнта, повинен проводиться послідовно, в заздалегідь встановлені терміни. На кожному наступному етапі

\section{Лiтература}

1. Глинчук Я. И. Клинические результаты применения жидких перфторорганических соединений в комплексном хирургическом лечении тракционных отслоек сетчатки с захватом макулярной области при пролиферативной диабетической ретинопатии / Я. И. Глинчук, С. А. Метаев, А. И. Саркисян //Офтальмохирургия. - 1996. - № 2. C. 7-12.

2. OshimaY. Surgical outcomes of 25-gauge transconjunctival vitrectomy combined with cataract surgery for vitreoretinal diseases / Y. Oshima, M. Ohji, Y. Tano // Ann. Acad. Med. Singapore. - 2006. -№ 35. - C. 175-180. необхідно зробити прогноз подальшого стану та очікуваного результату. Такий клінічний моніторинг як система спостереження, аналізу, оцінки та прогнозу стану хворих $\epsilon, з$ одного боку, засобом управління ризиками, а з іншого - системою підтримки прийняття рішень, що обумовлює оперативне та ефективне вирішення питань тактики проведення вітректомії при ПДР та надає пацієнтові відомості про його реальний ризик.

Висновки. 1. Підвищення вимог до управління станом пацієнта, що супроводжується збільшенням обсягу інформації, визначає необхідність застосування інформаційних технологій для прогнозування перебігу та результату лікувального процесу у пацієнтів з ДПР в режимі реального часу.

2. Розробка та впровадження системи прогнозування ризиків несприятливого результату і виникнення ускладнень хірургічного лікування сприяє об' єктивізації індивідуальної оцінки ризиків для кожного пацієнта, і дозволяє обгрунтувати час проведення оперативного втручання і оптимізувати надання офтальмологічної допомоги хворим з цукровим діабетом.

3. Родин С. С. Бевацизумаб (авастин) в комплексном хирургическом лечении больных с пролиферативной стадией диабетической ретинопатии / С. С. Родин В. С. Асланова // Український медичний альманах. - Луганск. - 2008. T. 11, №3, - С. 126-128.

4. Рубан А. М. Результата комбінованої $23 \mathrm{G}$ вітректомії 3 факоемульсифікацією та імплантацією ЮЛ у пацієнтів на проліферативну діабетичну ретинопатію // Офтальмологічнийжурнал - 2013.- №2. - С. 36-12.

5. Рубан А. М. Бімануальна міні-інвазивна техніка видалення заднього вітреошизису у пацієнтів на проліферативну 


\section{МЕДИЧНА ІНФОРМАТИКА}

\section{TA IHЖEHEPIЯ}

діабетичну ретинопатію // 36. наук, праць сігівробіт. НМАПО імені П. Л. Шупика-2013. - № 22 (4). - С. 90-98.

6. Рубан А. М. Інформаційне забезпечення стратегії визначення оптимальної тактики хірургічного лікування хворих 3 проліферативною діабетичною ретинопатією // Медична інформатика та інженерія. - 2011. - № 3. - С. 56-62.

7. Рубан А. М. Інформаційне забезпечення стратегії визначення оптимальної тактики хірургічного лікування хворих 3 проліферативною діабетичною ретинопатією // Медична інформатика та інженерія. - 2011. - №3. - С. 56-62.
8. Мінцер О. П. Інформаційні технології в хірургії / О. П. Мінцер, В. 3. Москаленко, С. В. Веселий. - В 10 книгах «Інформаційні технології в охороні здоров'я і практичній медицині». - Кн. 3. - К.: Виша школа, 2004. - 423 с.

9. Риюв С. О. Фактори ризику в прогнозуванні виходу хірургічного лікування проліферативної діабетичної ретинопатії / С. О. Риков, А. М. Рубан, А. Ю. Зольнікова // Медична інформатика та інженерія. - 2012. - № 1. - С. 16-22.

10. Recent outcomes of vitreous surgery for diabetic retinopathy/H. Oda, K. Konno, K. Mitsui [etal.]. //Nippon Ganka Gakkai Zasslii. - 2005 - № 109.-C. 603-612. 